\title{
ACHIEVING SUSTAINABLE SPATIAL DEVELOPMENT IN THE ALPS THROUGH PARTICIPATORY PLANNING
}

Janez Nared, Nika Razpotnik Visković, Dominik Cremer-Schulte, Riccardo Brozzi, Felipe Cortines Garcia

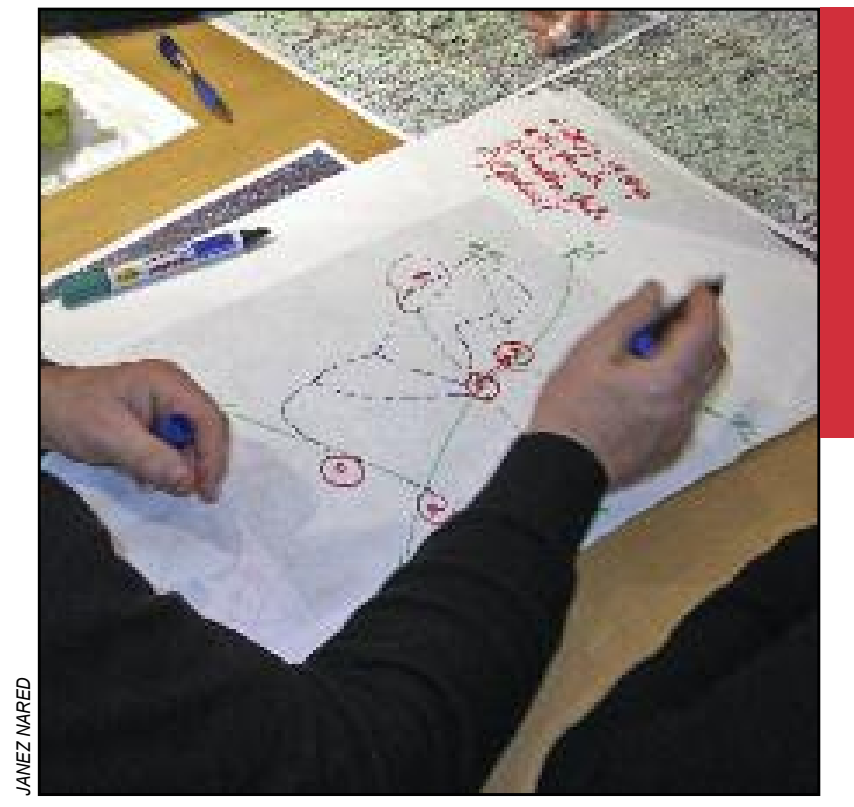

Shaping the plan. 


\title{
Achieving sustainable spatial development in the Alps through participatory planning
}

\author{
DOI: http:://dx.doi.org/10.3986/AGS.1631 \\ UDC: $913: 711(234.3)$ \\ 711:502.131(234.3) \\ COBISS: 1.01
}

\begin{abstract}
:
This article analyzes the legal frameworks of participatory planning in Alpine countries and assesses its role in achieving more sustainable spatial development in the Alps. Our research analyzed twenty-seven legal acts from seven Alpine countries and shows that the role of stakeholder participation in spatial planning has gradually increased. However, participation still remains at a rather unsatisfactory level, mainly because of its pro-forma character and practitioners' insufficient knowledge on how to implement it. To increase the use of participatory processes, it is important 1) to convince planning stakeholders that participation is a key instrument in ensuring sustainable spatial development and 2) to inform practitioners about participatory methods and techniques.
\end{abstract}

KEYWORDS: geography, spatial planning, participatory planning, Alps, sustainable development

The article was submitted for publication on January $20^{\text {th }}, 2015$.

\section{ADDRESSES:}

Janez Nared, Ph.D.

Anton Melik Geographical Institute

Research centre of the Slovenian academy of sciences and arts

Gosposka ulica 13, SI - 1000 Ljubljana, Slovenia

E-mail: janez.nared@zrc-sazu.si

Nika Razpotnik Visković, Ph.D.

Anton Melik Geographical Institute

Research centre of the Slovenian academy of sciences and arts

Gosposka ulica 13, SI - 1000 Ljubljana, Slovenia

E-mail: nika.razpotnik@zrc-sazu.si

\section{Dominik Cremer-Schulte}

National research institute of science and technology for environment and agriculture 2, rue de la papeterie, BP 76, F - 38402 Saint-Martin-d'Hères Cedex, Grenoble, France E-mail: dominik.cremer-schulte@irstea.fr

\section{Riccardo Brozzi}

Institute for regional development and location management

European academy of Bozen/Bolzano

Viale Druso, 1 / Drususallee 1, IT - 39100 Bolzano / Bozen, Italy

E-mail: riccardo.brozzi@eurac.edu

\section{Felipe Cortines Garcia}

Institute for regional development and location management

European academy of Bozen/Bolzano

Viale Druso, 1 / Drususallee 1, IT - 39100 Bolzano / Bozen, Italy

E-mail: felipe.cortines@eurac.edu 


\section{Introduction}

The Alps are one of the most remarkable European macro-regions. They face manifold development challenges, such as climate and demographic change followed by environmental and economic processes, and this constantly demands rapid and deliberate reaction to preserve the Alps' unique ecosystem and the wellbeing of the people that live there. In order to mutually address shared issues, the Alpine countries have agreed on common strategic objectives in the Alpine Convention, "an international treaty between the Alpine countries (Austria, France, Germany, Italy, Liechtenstein, Monaco, Slovenia, and Switzerland) as well as the EU, aimed at promoting sustainable development in the Alpine area and at protecting the interests of the people living within it « (Alpine Convention 2014). Preservation of the unique and sensitive Alpine environment must go hand in hand with human social and economic activities, and therefore appropriate and diversified measures should be applied in agreement with the local population, political representatives, and businesses and associations (Protocol ... 1994). Local stakeholders are brought to the fore and given a chance to determine their own territory's social, cultural, and economic development, with the conviction that many problems in Alpine territory can best be solved by the local and regional authorities directly concerned. In providing a framework for participation of local and regional authorities, each contracting country shall define the best level of coordination and cooperation between its institutions and regional and local authorities. In doing so, potential synergies might be better exploited and developed in implementing spatial planning and sustainable development policies and measures (Protocol ... 1994, Article 7).

In this regard »the regional and local authorities directly concerned shall be parties to the various stages of preparing and implementing these policies and measures, within their competence and within the existing institutional framework « (Protocol ... 1994, Article 7).

With the start of the third decade of carrying out the Spatial Planning and Sustainable Development Protocol (Protocol... 1994), this article analyzes the legal frameworks of participatory planning in the Alpine countries and assesses its role in achieving more sustainable forms of spatial development in the Alps. The analysis was conducted in the scope of the WIKIAlps project (Alpine Space Programme) and addressed two main research questions: 1) How and to what extent is participatory planning regulated across regions and countries in the Alps? 2) What are the strengths and weaknesses of the legal processes and instruments of participation?

\section{Methods}

Answering these questions required a background in planning theory, and a systematic analysis of nation$\mathrm{al}$ and regional legislations framing spatial planning and its implementation in the Alpine Space. In addition to a literature review of theoretical perspectives, we first implemented a screening of the legal framework in each Alpine country; in federal countries (e.g., Austria and Germany) regional legislation was also considered in this phase. We examined participatory processes and instruments, as well as their institutional structure and legal provisions for each territorial level. In doing so, we were able to gain an extensive overview of conditions across countries regarding participation (Section 4), which was necessary to facilitate comparisons between countries and regions. The second analytical step was an in-depth analysis of selected spatial planning processes, focusing on how participatory planning is implemented in practice. We were able to define and draw conclusions about the strengths and weaknesses of participatory planning in different countries and regions. Our results and conclusions are supported by primary and secondary literature, legislation, and practitioners' expert knowledge. The territory analyzed covers the entire Alpine Space. In evaluating the involvement of local stakeholders, we addressed local and regional authorities, as well as a large number of different social and economic groups such as businessmen, NGOs, private firms, and the local population.

\section{Participatory planning: A theoretical perspective}

Participatory planning is planning that includes stakeholders in the planning process. The aim of participatory planning is to foster partnerships and joint management instead of serving the vested interests of 
individual regional actors. Successful management of the participation process makes it possible to achieve many goals: ironing out differences between different perspectives, preventing unproductive competition, shaping solutions acceptable to all social groups, ensuring the participation and motivation of local actors, participants' identification with decisions that concern their environment, and strengthening their creativity and recognition. Incorporating the views of the public into planning decisions gives the decisions greater legitimacy (Hage, Leroy and Petersen 2009), and it increases empowerment and enhances vision-making and advocacy capabilities (Reed 2008; Ricketts 2008; Pacione 2014). It can be used to inform and involve a more diverse public audience, strengthen mutual understanding, cross interest relationships, explore and integrate new ideas and solutions that may not have been considered otherwise, and ensure that planning and decision-making are informed by the needs and interests of the communities affected (Sayce et al. 2013). The participation process strengthens regional identity, initiates a process of social learning, enhances local knowledge, and promotes comparative advantages based on local knowledge (Meyer 1999; Garofoli and Musyck 2001; Geoghegan, Renard and Brown 2004; Abels 2007; Zumaglini et al. 2008). Participatory processes require sensitive attention in order to not increase the socioeconomic differences between groups in the population, but instead reduce and eliminate such differences (Rauch, Bartels and Engel 2001; Nared and Razpotnik Visković 2014).

Participation also has its disadvantages, especially because of its duration and financial demands. Often individual groups are excluded if they do not have the knowledge, skills, and/or resources to participate in such a demanding and lengthy process. Additional weaknesses become manifest if the participation process is informal; that is, participants that lack legal backing are unable to take measures, their proposals are nonbinding, and their opportunities to carry out the decisions they adopt are also limited.

The role of participatory planning is exceptionally important because local cultures, geographical conditions, urban economic composition, local management styles, and local governance conditions are sitespecific and have a significant influence on planning decisions. Planning is thereby accorded higher quality, legitimacy, affiliation, and support from the population, which is a precondition for successfully implementing planning activities.

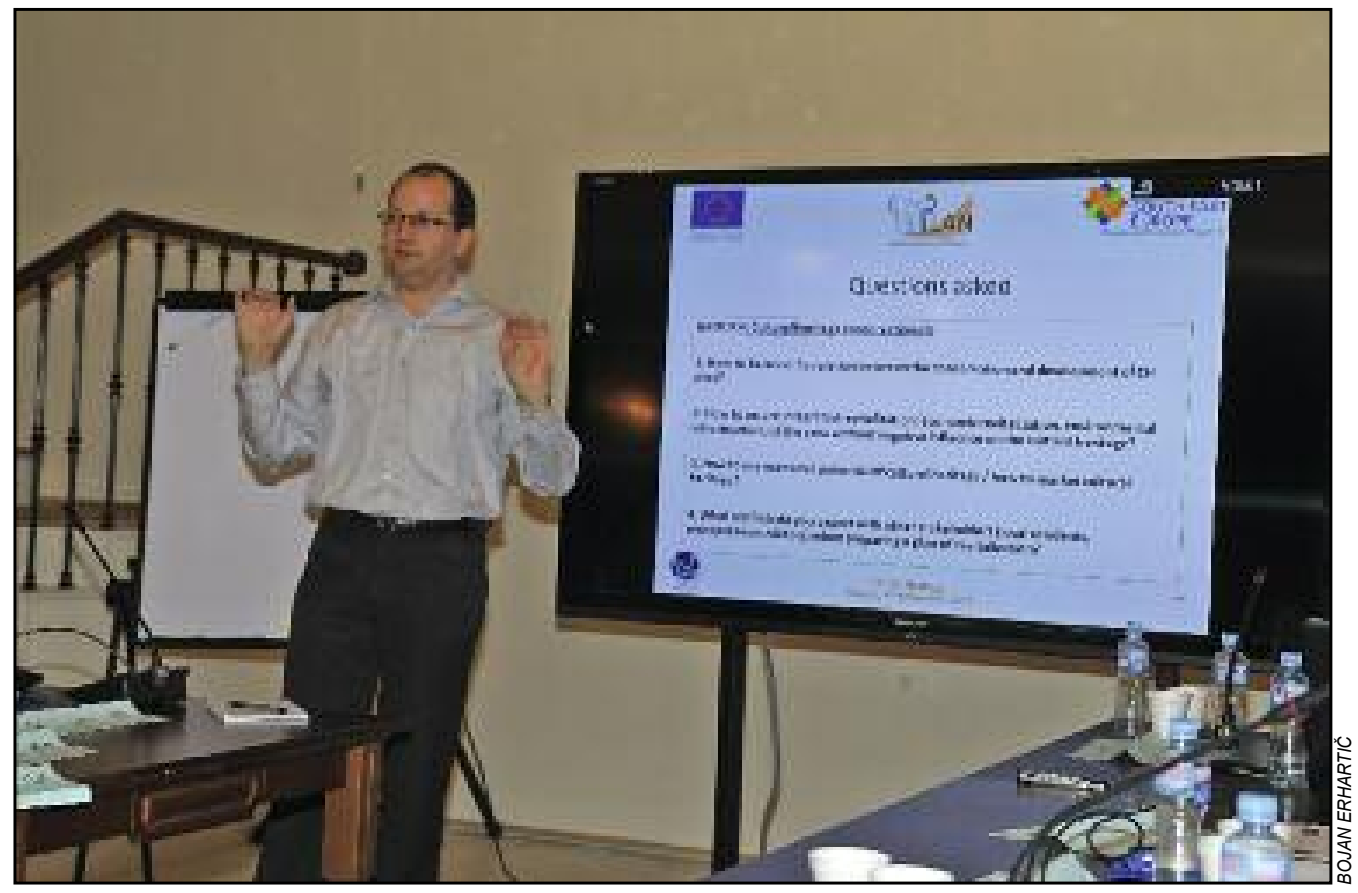

Figure 1: Workshop facilitation. 
However, it is not enough to simply invite regional actors to participate. It is necessary to take their opinions into account and to put them into practice to the greatest extent possible, thereby creating a communicative and non-adversarial environment for everyone (Nared and Razpotnik Visković 2014).

\section{Stakeholder involvement in participatory planning: Legal frameworks of spatial planning in the Alpine countries}

\subsection{Austria}

In Austria, there are three levels of government with regard to spatial planning: federal, state, and municipal. The federal government lacks the authority for comprehensive spatial planning, and laws are passed at the state level, which serves as a framework for the municipal level when implemented (European Communities 2000). The Austrian Conference on Spatial Planning (Österreichischen Raumordnungskonferenz ÖROK) coordinates (without any binding capacity) spatial development based on a political agreement at all three levels. Public participation is encouraged from here: „Generally, civil society stakeholder groups are to be addressed more proactively than up to now (Austrian ... 2011,94), but this is regulated by the regional spatial planning acts. In general terms, public participation is poorly implemented because draft plans only have to be made available four to six weeks before being adopted (Fülöp 2013). Participatory instruments are not compulsory and the authorities are not required to respond to proposals.

\subsection{France}

The participatory dimension of planning has gained importance in the French context over the last two decades. Around 2000, several laws significantly renewed the planning system and led to the rise of territorial governance around large-scale strategic planning projects (e.g., the Spatial Planning Law ... 1999; the Solidarity Law 2000). Recently, the Grenelle environmental laws (the Grenelle II Law 2010) fostered the role of sustainability in spatial planning and especially the public consultation instrument (Monédiaire 2011). At new larger territorial scales, especially city regions, nature parks, or municipal syndicates, local actors are encouraged to participate in integrated spatial planning and development strategies. These are jointly developed by local elected representatives in a bottom-up manner, based on negotiation and consensus. However, because strategic planning projects such as those of territorial cohesion schemes (SCOT) greatly depend on local consensus, planning perimeters might significantly vary in size (e.g., 273 municipalities for the Grenoble city region versus sixty-three for the Annecy city region).

\subsection{Germany}

Spatial planning in Germany is determined by its federal nature, with a division of competences at three levels: federation, federal states, and municipalities. Even though all levels are interrelated through the »feedback principle, « each level has its legal basis (Turowski 2002). At the federal level, the Spatial Planning Act (2008) sets out guidelines and provisions that coordinate and steer spatial planning, leaving federal states enough scope to legislate in their own interest. The municipalities set up local land-use planning. Public participation has been present in urban planning since the 1970s. Since the implementation of the EU strategic environment Assessment Directive (2001), the public has to be advised of the content of each spatial planning process (Knieling and Othengrafen 2009). Participation is ensured at the federal state and municipal levels because public participation is a compulsory step in drafting any plan and before adoption (Turowski 2002).

\subsection{Italy}

In Italy, decentralization reforms since the 1990s have shifted planning powers (in terms of territorial governance) to regions, provinces, metropolitan areas, and municipalities, which started including multi-actor 
planning actions, public private coalitions, and participatory processes for strategic local and regional development (Reimer et al. 2014). Although many emerging examples of informally regulated initiatives exist across the entire country, mainly at the municipal level (Bobbio 2007; Arena and Cortese 2011), participatory processes in spatial planning are seldom mandatory. At the national level, there is no legislation with binding effects on participation processes. At the regional level and for the moment, the most complete legislation promoting participation in creating regional laws is reported outside the Alpine Space Program Area, in the regions of Emilia-Romagna (Regione ... 2010) and Tuscany (Regione ... 2013).

\subsection{Liechtenstein}

With its manageable size $\left(160 \mathrm{~km}^{2}, 36,000\right.$ inhabitants), Liechtenstein, like Switzerland, has a system of direct democracy with optional, obligatory, and population-initiated referendums. Unlike Switzerland, population-initiated referendums are less common and have more of the function of an emergency brake for citizens (Marxer and Pállinger 2007). The prince, however, has veto power. The lack of a spatial planning act is often regarded as a problem. Only the National Building Law (Regierung ... 2008) and Planning Law (Regierung... 1992) regulate spatial planning procedures and define their instruments. The National Structure Plan (Regierung ... 2011), approved by the national government, aims to coordinate future spatial development, landscape conservation, and transport goals at the national scale but is only binding for national public authorities. The municipal plans determine land use and construction at the municipal level (Pütz et al. 2011). More informal participation than consultation is not defined in legislation.

\subsection{Slovenia}

In Slovenia, participation processes have been integrated in spatial development since the 1960s. They were carried out in the form of public displays of land use and location plans and public hearings afterwards (Zakon ... 1967). The Aarhus Convention (Convention ... 1998) has expanded the concept of public participation and exceeds its environmental scope. Its rights-based approach has been integrated into several Slovenian laws that are relevant for sustainable spatial development. Unfortunately, however, the current implementation practice does not follow the legislative framework (Baloh 2013). The compulsory nature of these provisions gives the false impression that every planning decision is made with public consent. Notably, they are positioned at the very end of the planning process and their role is reduced to granting the process legitimacy by presenting the predetermined proposal to the public. People are thus deprived of the opportunity to contribute effectively and creatively to plans and decisions about their own future and living environment. They can only agree to or oppose the proposed solution (Golobič and Marušič 2007).

\subsection{Switzerland}

Except for the cantons of Geneva and Basel-City, land-use planning generally lies in the jurisdiction of municipalities with various degrees of freedom (depending on cantonal laws). Although consultation between administrative services is frequent in spatial planning, informal participation with non-administrative stakeholders remains the exception (Luyet et al. 2012). Since 1979, the federal law on spatial planning requires public involvement of the population in spatial planning procedures. These prerequisites are translated into the spatial planning laws of the cantons, which give everyone concerned the right to oppose a project. Direct participation, however, has led to difficulties in completing procedures because opposing parties often block planning and construction projects. Therefore, public authorities at all levels have to take into account public opinion and stakeholder interests while planning and developing a project in order not to risk an opposing popular initiative.

\section{Participation in practice}

In studying the implementation of participatory planning throughout the Alpine countries and regions, we developed a matrix (Table 1) listing the country, name of the act, territorial level, domain, scope of the par- 
ticipatory processes, and strengths and weaknesses of its implementation for selected legal acts in sustainable spatial development.

Table 1: Matrix on participatory planning in the Alpine countries and regions.

\begin{tabular}{|c|c|c|c|c|c|}
\hline Country & Act & $\begin{array}{l}\text { Territorial level } \\
(N=\text { national, } \\
R=\text { regional, } \\
L=\text { local) }\end{array}$ & $\begin{array}{l}\text { Domain } \\
(S P=\text { spatial planning \& } \\
\text { land use, } \mathrm{E}=\text { environment, } \\
\mathrm{RD}=\text { regional development) }\end{array}$ & $\begin{array}{l}\text { Participation } \\
\text { ( } \mathrm{M}=\text { mandatory, } \\
0=\text { optional, } \\
\text { (= consultations) }\end{array}$ & $\begin{array}{l}\text { Implementation } \\
\text { (strengths and weaknesses) }\end{array}$ \\
\hline
\end{tabular}

Altogether, twenty-seven legal acts were identified. Among them, three relate to the national level, four to the regional level, and three to the local level. Furthermore, some acts refer to two or more levels: three to both national and local, two to both regional and local, ten to both national and regional, and two to all three levels. Twenty-two acts come from the domains of spatial planning and land use, two from the environment, two from regional development, and one horizontally covering all three topics.

In terms of jurisdiction, the local and regional levels have the greatest influence on spatial development and planning, and from the perspective of the inclusion of regional and local authorities in spatial planning decisions the requirements of the Spatial Planning and Sustainable Development Protocol (Protocol ... 1994) are fully met. The opposite result can be seen when the participation of various social and economic groups (the local population, businessmen, NGOs, etc.) is in question. The majority of acts foresee consultations with those interested, but mostly at the end of the planning process, and they are often regarded as a »necessary evil« by planners.

Participation legislation and processes at the national level are particularly weakly developed because participation at this scale is most demanding due to a large number of stakeholders. In addition, gaps have been identified in the knowledge and competences of stakeholders (Lederer 2009).

Although participation increasingly becomes a must in spatial planning, regulation of the participatory process such as tasks for citizens, types of intervention, and consultation modalities are often not provided in detail. Consequently, its extent is often limited to the formal submission of opinions from public authorities, departments, and associations, and post-process consultation of the population. At the local level, due to a lack of resources, participation can often be reduced to a minimum without harming the legal force.

When the participatory process exceeds administrative levels, it occurs in most cases in the form of non-binding consultations, limited to interested landowners or investors, whereas the coordinators are not obliged to consider the public remarks - they only have to take a stand towards them. Practices of bottom-up strategic planning and a wider debate on sustainable spatial development are still very rare.

Despite the deficiencies described above, a trend towards a renewal of planning culture in the form of cooperative and communicative planning could be observed (Partizipation ... 2014; Healey 2004). Participation is becoming an integral part of almost all legal acts, and in some cases minimum standards are expected, such as providing early information to citizens and participation of crucial stakeholders in the preparation process in the form of working and focus groups, dialogs, public presentations, and so on. For instance, the legislation in Vorarlberg, Austria, perceives participation as one of the decisive orientations for future decisions at the state level. In order to promote such processes, the state has prepared a handbook (Handbuch ... 2010) to improve the implementation of participatory processes at the municipal and regional level. In France, the recent environmental turn in legislation (the Grenelle laws of 2009 and 2010) has reinforced public participation by extending its scope. The legal framework now ensures participation throughout the entire process and defines participation as the only instrument that can have legal constraining effects on administrative decisions. In this way, the Grenelle laws made participation a tool for serious participatory democracy.

Good-practice example comes from the Tyrolean government, which used participatory planning for its spatial development strategy, ZukunftsRaum Tirol (2011). In Vorarlberg, another strategic development vision is the Vis!on Rheintal. Its development was based on an open participatory and development process among twenty-nine municipalities, which see their valley as one living space and aim at pulling resources together (2015; Partizipation ... 2014). In Lower Austria, the WIN Strategie Niederösterreich (Strategie NÖ 2010) is another good example of the joint and collaborative development of a state strategy. 


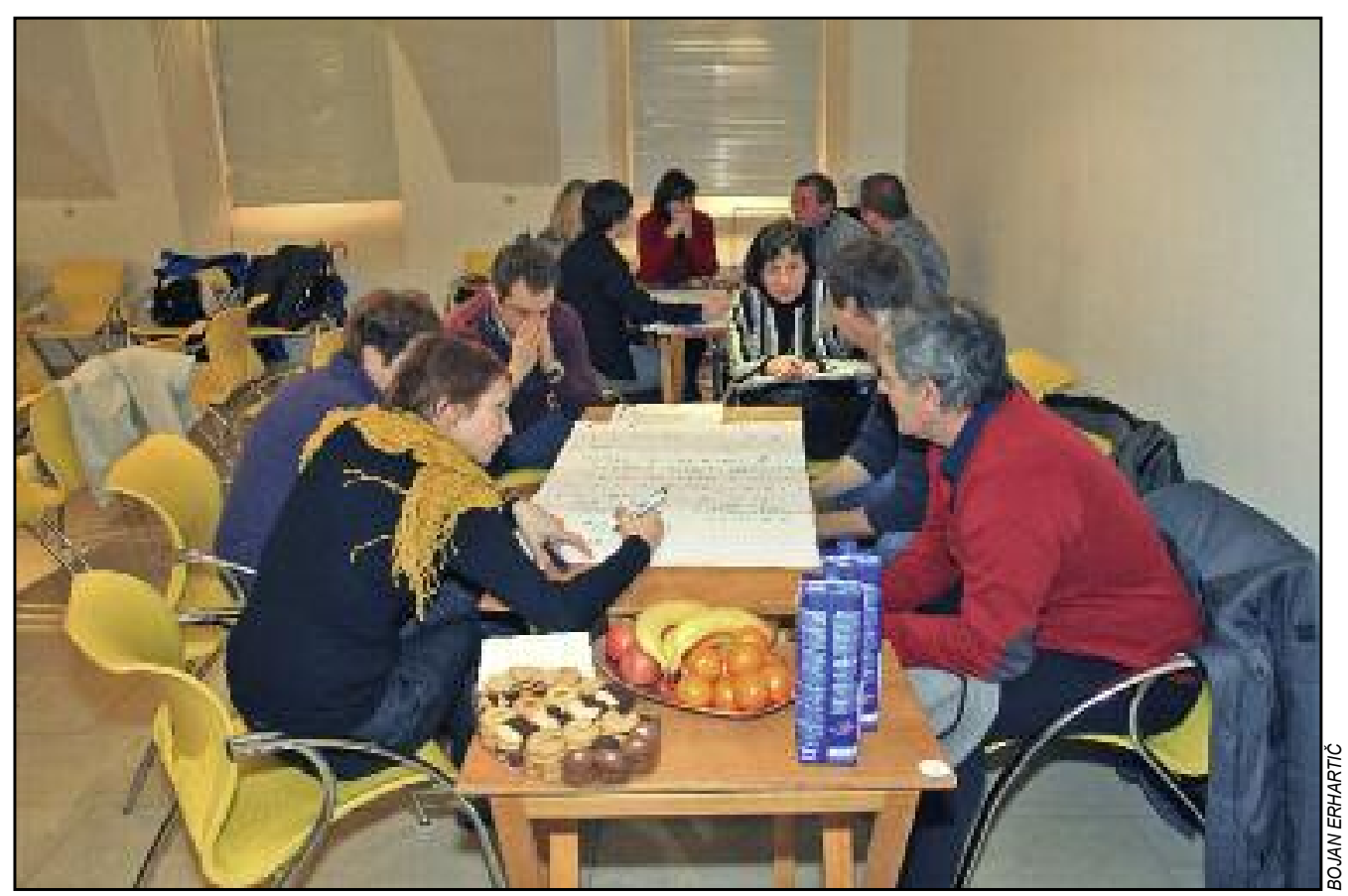

Figure 2: Workshop in Idrija, Slovenia.

When speaking of participatory democracy, one cannot neglect the planning culture in Switzerland, where the national Spatial Planning Law (1979) requires the public to be properly informed regarding planning goals and procedures. The authorities have to ensure public participation in an adequate manner and, in addition to this, there are some informal initiatives for broad discussions among specialists and other stakeholders about spatial development and visioning at the national and regional levels.

Sometimes participatory processes are also used outside existing legal frameworks, mainly initiated by individual decision-makers aware of the benefits that public participation could provide. A good example is the Innovative Strategy for Sustainable Development of the Municipality of Idrija (Slovenia; Nared et al. 2011). Its preparation fully relied on information that was gathered through a range of workshops, questionnaires, and interviews.

\section{Conclusions}

This article has provided a valuable overview of how participation is integrated in national and regional spatial planning legislation throughout the Alpine Space. Legal provisions for spatial planning and especially participation vary substantially from one country to another, often even between regions of the same country. Legal provisions respect specific institutional and territorial landscapes as well as national planning cultures, whereas the main responsibility for sustainable spatial planning is given to regional and local authorities. More specifically, in terms of participation, the analysis showed that the role of stakeholder participation in spatial planning has gradually increased. However, from a normative perspective and with respect to planning theory, the analysis has revealed weaknesses in the implementation of participation. Some further progress is required in order to meet theoretical principles of good governance and to incorporate lessons learned from good practices. The main reasons for this inconvenient status lie in 1) rather vague legislative provisions that mostly stipulate participation only in a pro-forma sense (i.e., in terms of mandatory disclosure of the plan before its final approval), and 2) in a lack of precision concerning methods and 
techniques (i.e., insufficient and vague instructions for planners and authorities at the local level on how to implement and benefit from the participatory process). Planners often do not possess sufficient resources and competences to 1) evaluate the extent of participation needed, 2) implement participation processes with all relevant stakeholders and facilitate them, and 3) include the resulting findings in their plans.

Although extensive, our study was not able to identify the contribution of participatory planning to sustainable spatial development. We mostly focused on legislative frameworks and less on the actual implementation of participatory processes, neglecting potential regional and local socioeconomic and spatial effects of its implementation. Therefore, the issue of greater sustainability still remains at a hypothetical level, assuming that the role of participatory planning is exceptionally important because local cultures, geographical conditions, urban economic composition, local management styles, and local governance conditions are site-specific and have a significant influence on planning decisions (Zumaglini et al. 2008). It thus appears crucial for participatory processes to be adapted to local contexts in terms of needs and limitations, which will provide favorable input for more balanced and finely-tuned decisions and measures that should yield greater sustainability.

To increase the use of participatory processes at the regional and local levels, the Alpine countries should focus on systematically including participation in relevant regulations in spatial planning and should provide detailed instructions on how to implement this in different contexts. The authorities could also strengthen participatory planning for ongoing education and expertise-sharing among planners, informing them about participatory methods, tools, procedures, and theory. In this way, plans and concepts would not only receive greater acceptance among stakeholders and the general public, but they would also be better suited to local and regional conditions. The authorities could also draw lessons from positive examples of participatory planning in some Alpine regions, where participation has more comprehensive legislation. There is much local experience that can enhance stakeholders' participation through participatory democracy, growing awareness of the benefits of participation, and enhanced development of participatory techniques and tools. In this regard, participation and good governance should be considered fundamental pillars, rather than mere contributing elements, for more sustainable spatial development.

\section{Sources}

Abels, G. 2007: Citizen involvement in public policy-making: does it improve democratic legitimacy and accountability? The case of pTA. Interdisciplinary information sciences 13-1. DOI: http://dx.doi.org/ 10.4036/iis.2007.103

Alpine convention, 2014. Internet: http://www.alpconv.org/en/convention/default.aspx (11.9.2014).

Arena, G., Cortese, F. 2011: Per governare insieme: il federalismo come metodo. Verso nuove forme della democrazia. Milano.

Austrian spatial development concept, 2011. Internet: http://www.oerok.gv.at/fileadmin/Bilder/2.Reiter-Raum_ u._Region/1.OEREK/OEREK_2011/Dokumente_OEREK_2011/OEREK_2011_EN_Downloadversion.pdf (10.8.2014).

Baloh, T. 2013: Primerjalno-pravni pregled sistema prostorskega načrtovanja glede sodelovanja javnosti. Ljubljana. Internet: http://mrezaprostor.si/wp-content/uploads/2013/05/Primerjalno-pravni-pregledsodelovanja-javnosti-pri-OPN.pdf (1.9.2014).

Bobbio, L. 2007: Amministrare con i cittadini. Viaggio tra le pratiche di partecipazione in Italia. Presidenza del Consiglio dei ministri. Dipartimento della funzione pubblica. Roma.

Convention on access to information, public participation in decision-making and access to justice in environmental matters, 1998. Aarhus. Internet: http://www.unece.org/fileadmin/DAM/env/pp/documents/ cep43e.pdf (15.11.2015).

European communities 2000: The EU compendium of spatial planning systems and policies - Austria. Regional development studies series. Luxembourg.

European parliament 2001: EU strategic environment assessment of the effects of certain plans and programmes on the environment. Directive 2001/42/EC. Internet: http://eur-lex.europa.eu/legal-content/ EN/TXT/?uri=CELEX:32001L0042 (20.1.2015).

Fülöp, S. 2013: Public participation in spatial planning procedures. Comparative study of six EU member states. Justice and environment. Internet: http://www.justiceandenvironment.org/_files/file/2013/ Land\%20use\%20planning\%20and\%20access.pdf (20. 1.2015). 
Garofoli, G., Musyck, B. 2001: Innovation policies for SMEs in Europe: Towards an interactive model? Regional studies 35-9.

Geoghegan, T., Renard, Y., Brown, N. A. 2004: Guidelines for participatory planning: a manual for Caribbean natural resource managers and planners. Port of Spain.

Golobič, M., Marušič, I. 2007: Developing an integrated approach for public participation: a case of land-use planning in Slovenia. Environment and planning B: planning and design 34. DOI: http://dx.doi.org/ $10.1068 / \mathrm{b} 32080$

Hage, M., Leroy, P., Petersen, A. C. 2010: Stakeholder participation in environmental knowledge production. Futures 42. DOI: http://dx.doi.org/10.1016/j.futures.2009.11.011

Healey, P. 2004: The treatment of space and place in the new strategic spatial planning in Europe. International journal of urban and regional research, 28-1. DOI: http://dx.doi.org/10.1111/j.0309-1317.2004.00502.x

Handbuch Bürgerbeteiligung für Land und Gemeinden. 2010. Amt der Vorarlberger Landesregierung, Bregenz. Internet: http://www.vorarlberg.at/pdf/handbuchbuergerbeteiligun.pdf (7.10.2014).

Knieling, J., Othengrafen, F. 2009: Planning cultures in Europe. Decoding cultural phenomena in urban and regional planning. Farnham.

Law Grenelle I, France, 2009: Law n 2009/967 du 3 août 2009 de programmation relative à la mise en œuvre du Grenelle de l'environnement. Paris. Internet: http://www.legifrance.gouv.fr/affichTexte.do?cidTexte= JORFTEXT000020949548 (20.1.2015).

Law Grenelle II, France, 2010: Law n ${ }^{\circ} 2010 / 788$ du 12 juillet 2010 portant engagement national pour l'environnement. Paris. Internet: http://www.legifrance.gouv.fr/affichTexte.do?cidTexte=JORFTEXT $000022470434(20.1 .2015)$.

Law for spatial planning and sustainable development, France, 1999: Law no 99-533 du 25 juin 1999 d'orientation pour l'aménagement et le développement durable du territoire et portant modification de la loi no 95-115 du 4 février 1995 d'orientation pour l'aménagement et le développement du territoire. Paris. Internet: http://www.legifrance.gouv.fr/affichTexte.do?cidTexte=JORFTEXT000000760911\& categorieLien $=\mathrm{id}(20.1 .2015)$.

Law Solidarity and urban renewal, France, 2000: Law n ${ }^{\circ}$ 2000/1208 du 13 décembre 2000 relative à la solidarité et au renouvellement urbains. Paris. Internet: http://www.legifrance.gouv.fr/affichTexte.do? cidTexte=JORFTEXT000000207538\&dateTexte $=\&$ categorieLien $=i d(20.1 .2015)$.

Lederer, M. 2009: Positionspapier Partizipation. Vorarlberg. Internet: http://www.vorarlberg.at/pdf/ positionspapier_vers7.pdf (7.10.2014).

Luyet, V., Schlaepfer, R., Parlange, M. B., Buttler, A. 2012: A framework to implement Stakeholder participation in environmental projects. Journal of environmental management 111. DOI:http://dx.doi.org/ 10.1016/j.jenvman.2012.06.026

Marxer, W., Pállinger, Z. T. 2007: System contexts and system effects of direct democracy - direct democracy in Liechtenstein and Switzerland compared. Direct democracy in Europe: developments and prospects. Wiesbaden.

Meyer, J. A. 1999: Regionalmarketing: Grundlagen, Konzepte, Anwendung. München.

Mo.Re.Co. Belluno, 2014. Internet: http://www.morecobelluno.eu/ (4. 8. 2014).

Monédiaire, G. 2011: La participation du public organisée par le droit?: des principes prometteurs, une mise en œuvre circonspecte. Paris. DOI: http://dx.doi.org/10.3917/parti.001.0134

Nared, J., Razpotnik Visković, N. 2014: Managing cultural heritage sites in Southeastern Europe. Ljubljana.

Nared, J., Smrekar, A., Bole, D., Kozina, J., Fridl, J., Polajnar Horvat, K., Gabrovec, M., Repolusk, P., Zavodnik Lamovšek, A., Sever, B. 2011: Inovativna strategija trajnostnega razvoja Občine Idrija. Geografski inštitut Antona Melika ZRC SAZU, Ljubljana.

Regierung des Fürstentums Liechtenstein, 2008: Baugesetz (BauG) vom 11. Dezember 2008, 701.0. Internet: https://www.gesetze.li/Seite2.jsp?LGBlm=2009044 (20.1.2015).

Regierung des Fürstentums Liechtenstein, 1992: Gesetz vom 25. März 1992 über die Erhaltung und Sicherung des landwirtschaftlich nutzbaren Bodens), 702.1. Internet: https://www.gesetze.li/Seite2.jsp?LGBlm= 2009044 (20.1.2015).

Regierung des Fürstentums Liechtenstein, 2011: Landesrichtplan. Liechtenstein, 2011. Internet: http://www.llv.li/ files/abi/pdf-llv-slp-lrpl-gesamtbericht_3-2011.pdf (20.1.2015).

Pacione, M. 2014: The power of public participation in local planning in Scotland: the case of conflict over residential development in the metropolitan green belt. GeoJournal 79. DOI: http://dx.doi.org/ 10.1007/s10708-013-9477-y 
Partizipation \& nachhaltige Entwicklung in Europa. Internet: http://www.partizipation.at/835.html (9. 10.2014).

Protocol on the implementation of the Alpine convention of 1991 relating to spatial planning and sustainable development, 1994. Internet: http://www.alpconv.org/en/convention/protocols/Documents/Protokoll_ RaumplanungGB.pdf (11.9.2014).

Pütz, M., Kruse, S., Casanova, E., Butterling, M. 2011: Climate change fitness of spatial planning. WP 5 Synthesis Report. ETC Alpine Space Project CLISP. Birmensdorf.

Rauch, T., Bartels, M., Engel, A. 2001: Regional rural development: A regional response to rural poverty. Wiesbaden.

Reed, M. S. 2008: Stakeholder participation for environmental management: a literature review. Biological conservation 141-10. DOI: http://dx.doi.org/10.1016/j.biocon.2008.07.014

Reimer, M., Getimis, P., Blotevogel, H. H. 2014: Spatial planning system and practices in Europe. A comparative perspective on continuity and changes. New York.

Regione Emilia Romagna 2010: Regional Law 3/2010. Internet: http://demetra.regione.emilia-romagna.it/al/ monitor.php?vi=nor\&urn=er:assemblealegislativa:legge:2010;3 (24.7.2014).

Regione Toscana 2013: Regional Law 46/2013. Internet: http://raccoltanormativa.consiglio.regione.toscana.it/ formati/stampepdf/legge-2013-00046.pdf (24.7.2014).

Ricketts, A. 2008: Participation in place-making: Enhancing the wellbeing of marginalised communities in Aotearoa/New Zealand. Internet: http://www.chranz.co.nz/pdfs/a-ricketts-participation-in-place-making.pdf (1.3.2014).

Sayce, K., Shuman, K., Connor, D., Reisewitz, A., Pope, E., Miller-Henson, M., Poncelet, E., Monié, D., Owens, B. 2013: Beyond traditional stakeholder engagement: Public participation roles in California's statewide marine protected area planning process. Ocean and coastal management 74. DOI: http://dx.doi.org/ 10.1016/j.ocecoaman.2012.06.012Spatial Planning Act, Germany, 2008: Raumordnungsgesetz vom 22.12.2008. Internet: http://www.gesetze-im-internet.de/bundesrecht/rog_2008/gesamt.pdf (20.1.2015).

Spatial planning law, Switzerland, 1979: Bundesgesetz über die Raumplanung (Raumplanungsgesetz, RPG) vom 22. Juni 1979 (Stand am 1. Mai 2014). Internet: http://www.admin.ch/opc/de/classified-compilation/ 19790171/index.html (20.1.2015).

Strategie NÖ - die BürgerInnenbeteiligung im Überblick. 2010. Internet: http://www.noe.gv.at/Land-Zukunft/ Landesentwicklung-Strategie-NOe/Strategie-NOe/Strategie_BuergerInnenbeteiligung.html (13.1.2015).

Turowski, G. 2002: Spatial planning in Germany - Structures and concepts: Studies in spatial development. Hannover.

Vis!on Rheintal. Bregenz, 2015. Internet: http://www.vision-rheintal.at/aktuelles.html (15. 1.2015).

Zakon o urbanističnem planiranju. Uradni list Socialistične Republike Slovenije 26/1967. Ljubljana.

ZukunftsRaum Tirol_2011. Innsbruck, 2011. Internet: https://www.tirol.gv.at/fileadmin/themen/ landesentwicklung/raumordnung/zukunftsraum/downloads/ROPlan_ZukunftsRaum_110927_web.pdf (15.1.2015).

Zumaglini, M., Nared, J., Alfarè, L., Razpotnik, N., Urbanc, M. 2008: Participation process in regional development: DIAMONT's perspective. Arbeitshefte/Quaderni 52. Bolzano/Bozen. 
